\title{
Formation of artificial beachrock towards inhibit of coastal erosion in Bangladesh: a review
}

\author{
Md. Nakibul H. Khan ${ }^{\text {i) }}$ and Satoru Kawasaki ${ }^{\text {ii) }}$

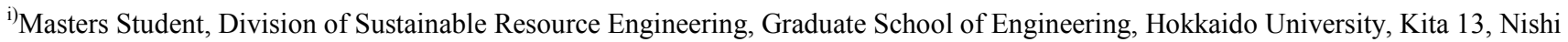 \\ 8, Kita-ku, Sapporo 060-8628, Japan \\ ii) Professor, Division of Sustainable Resource Engineering, Faculty of Engineering, Hokkaido University, Kita 13, Nishi 8, Kita-ku, \\ Sapporo 060-8628, Japan
}

\begin{abstract}
Erosion in the coastal area of Bangladesh is a big point of concern. The present study was conducted to find out the protective measure from coastal erosion in Bangladesh as well as evaluate the prospects of the formation of artificial beachrock. This study was conducted based on literature survey of related works. In the coast of Bangladesh, average recession through erosion will occur $0.87 \mathrm{~m}$ due to per $1 \mathrm{~cm}$ sea level rise. Beachrock as well as artificial beachrocks have the potentiality to prevent such coastal erosion. Beachrock is a type of sedimentary deposit that generally occurs on the tropical and subtropical beaches as a result of intertidal lithification of loose beach sands and gravels by carbonate cementation. Beachrock in the world differs by their chemical composition but it composed mainly of $\mathrm{CaCO}_{3}, \mathrm{SiO}_{2}$ and $\mathrm{Al}_{2} \mathrm{O}_{3}$. Usually, beachrocks are formed by the cementation of $\mathrm{CaCO}_{3}$ precipitation with the influence of seawater and/or seawater evaporation as well as surface microorganisms. From the knowledge of natural beachrock formation as well as sand properties, in the future, it may possible to manufacture artificial beachrocks similar to beachrocks for erosion control purposes in Bangladesh.
\end{abstract}

Keywords: Artificial beachrock, coastal erosion, carbonate cementation, seawater, surface microorganism

\section{INTRODUCTION}

Some islands in the world are in danger of being submerged due to erosion and sea level rise as impact of climate change. Bangladesh, the largest delta of the world, is the most vulnerable country to the impact of climate change. It is predicted that $17 \%$ of the total land of the country will be submerged if sea level rise up to 1.0 meter by 2100 and also predicted that sea level rise between 0.18 to 0.79 meters will lead to salinity intrusion and coastal flooding (Cruz et al., 2007). Erosion in the coastal area of Bangladesh is a big point of concern. Heavy discharge currents through the GBM (Ganges-Brahmaputra-Meghna) river system, wave action due to strong southwest monsoon winds, high astronomical tides, and storm surges in the Bay of Bengal are the main causes of erosion in the coastal area of Bangladesh (Ali, 1999). Superimposed on these causes, sea level rise (SLR) has a long-term effect on coastal erosion in the country.

Artificial beachrocks (manufacture artificially in the natural condition) have the potential to inhibit coastal erosion (Danjo and Kawasaki, 2013a and Danjo et al., 2013a). Beachrocks are coastal deposits cemented mainly by calcium carbonate cement; these deposits are found in the tidal and intertidal zone of sandy beaches in tropical and subtropical regions
(Danjo and Kawasaki, 2013a and Danjo et al., 2013a). Cox's Bazar sea beach of Bangladesh, the longest continuous beach of the world, is such types of sandy beach located subtropical region. Therefore this beach has the potentiality to the formation of artificial beachrock. Considering the use of artificial rock in order to preserve such submerged-looking islands above sea level, Danjo and Kawasaki (2012a, 2012b) and Danjo et al. (2012) conducted several study in Okinawa and Ishikawa, Japan. They found sufficient information to build artificial beachrock. Considering this importance such type of study is also essential in Bangladesh, as most vulnerable country to climate change, to inhibit the coastal erosion due to sea level rise using artificial rock.

Therefore the objectives of the present study were to find out the protective measure for coastal erosion in Bangladesh and to find the prospects of the formation of artificial beachrock.

\section{METHODS}

Data were gathered on (a) coastal erosion in Bangladesh, (b) beachrocks, its (c) properties and (d) formation mechanism; since this data would be essential for the manufacturing of artificial rock for the protection of coastal erosion. Data used in this study was obtained from literature survey of related 
works. Quantitative scenario of coastal erosion in Bangladesh was shown in the obtained data. Regional information for the substances contained in beachrocks, their cement components etc. were collected and compared. The chemical composition of beachrock and its physical and mechanical properties as well as formation mechanism data were also compiled.

\section{RESULTS AND DISCUSSIONS}

\subsection{Coastal erosion in Bangladesh}

Pramanik (1983), MCSP (1992), and Islam et al. (1999) studied coastal erosion and accretion activities in Bangladesh. Heavy discharge currents through the GBM (Ganges-Brahmaputra-Meghna) river system, wave action due to strong southwest monsoon winds, high astronomical tides as well as sea level rise (SLR), and storm surges in the Bay of Bengal are the main causes of erosion in the coastal area of Bangladesh (Ali, 1999). Erosion due to SLR has been discussed by Islam et al. (1999) at his study which was done under the U.S. Country Studies Program, and some of the salient features of the study are presented here. The study was based on the erosion formula given by Bruun (1962).

$$
x=a b /(e+d)
$$

Where $x$ is the shoreline recession due to SLR, $a$ is the rise in water level due to SLR, $e$ is the elevation of the shore, and $d$ is the depth of water at a distance $b$ from the coastline.

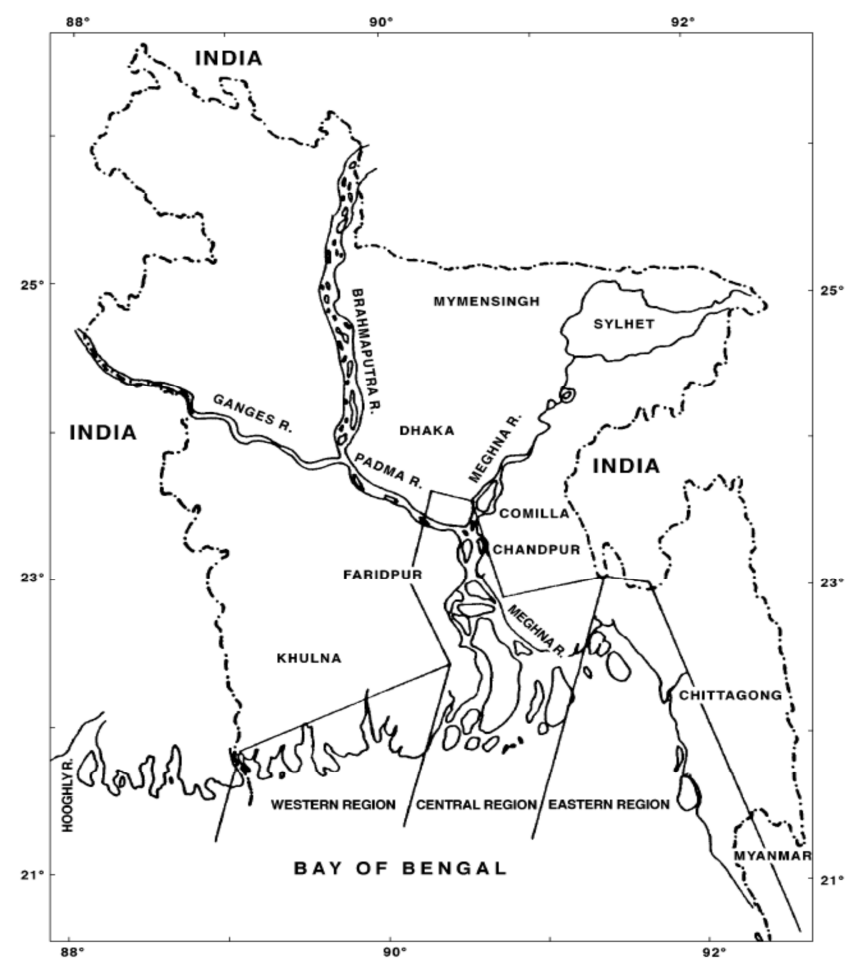

Fig. 1. Map of Bangladesh showing coastal area and the major river system (Islam et al., 1999)
Islam et al. (1999) applied the formula to the eastern region, where the longest continuous sandy beach situated, of Bangladesh (Fig. 1); the study area is bounded by $20^{\circ} 40^{\prime} \mathrm{N}$ and $22^{0} 13.5^{\prime} \mathrm{N}$ latitudes and $91^{\circ} 45^{\prime} \mathrm{E}$ and $92^{\circ} 2^{\prime} \mathrm{E}$ longitudes. Islam et al. (1999) also conducted a field survey at 21 different locations along the coast with profiles being perpendicular to the coastline to measure the values of the parameters. The recession distances were calculated for these points under 3 values of SLR - 0.30, 0.75, and $1.00 \mathrm{~m}$. $\mathrm{He}$ found, for $0.30 \mathrm{~m}$ SLR, the recession varies from 0.18 to $0.39 \mathrm{mcm}^{-1}$ (meaning that the shoreline will recede 0.18 to $0.39 \mathrm{~m}$ per $1 \mathrm{~cm}$ rise in SLR); for $0.75 \mathrm{~m}$, the range is 0.41 to $0.91 \mathrm{mcm}^{-1}$; and for $1.00 \mathrm{~m}, 0.58$ to $1.30 \mathrm{mcm}^{-1}$. On average, a recession of $0.87 \mathrm{~m}$ occurs per $1 \mathrm{~cm}$ rise in sea level. That is, recession distance through erosion due to SLR is about 87 times of the SLR. The results agree reasonably well with others; for example, 100 times for the Florida coast (Bruun 1962) and 60 to 80 times for the Belgium-to-Denmark coast (Hekstra 1989).

\subsection{Coastline protection through beachrock}

Natural beachrocks, which are formed naturally on beaches, have attracted attention as a model for artificial rocks. Danjo and Kawasaki (2013a) proposed a new method to protect coastlines from erosion - the use of artificial rock that auto-repairs by means of sunlight, seawater, and bacteria. Their model of artificial rock is beachrock. Beachrock is a type of sedimentary deposit that generally occurs on tropical and subtropical beaches as a result of intertidal lithification of loose beach sands and gravels by carbonate cementation (Ginsburg, 1953). The Association for Geological Collaboration in Japan (2000) defined beachrock are as follows:

"An extremely recent, consolidated, calcareous rock occurring in the intertidal zone on sandy beaches. It comprises multiple layers, each around 1-60 cm thick, and runs roughly in the same direction as the beach, at an oblique angle of $5-7^{0}$ to the sea. It forms a cuesta shape, with the landward side having an acutely angled face. Its overall thickness is about 1.0 $\mathrm{m}$, and may be separated into two or more bands. The cement material may be calcareous or may contain iron, and the non-cement substances may be any material, regardless of the grain size or substance. Beachrocks are found on beaches in tropical and subtropical zones. In the seas around Japan they can be found in the Nansei Island group, which is southwest of the mainland."

Around the world beachrocks have been reported to form over several thousand years (Vousdoukas et al., 2007) owing to interactions among sand supply, cement precipitation from seawater and coastal erosion by ocean waves (Danjo and Kawasaki, 2013a). Therefore, it may be possible to slow down the 
erosion of coasts by making man-made beachrock from coastal sands. Because this artificial rock is made of local materials, it has the potential to be an eco-friendly product (Danjo and Kawasaki, 2013a).

\subsection{Beachrock properties}

More than $90 \%$ of beachrocks are distributed between $40^{\circ} \mathrm{N}$ latitude and the Tropic of Capricorn, and that their formative periods ranges from 26,000 years to just a few decades ago (Danjo and Kawasaki, 2013b). Beach of Bangladesh located between $20^{\circ} 35^{\prime}$ $\mathrm{N}$ to $22^{0} 50^{\prime} \mathrm{N}$ latitude and $89^{0} 06^{\prime} \mathrm{E}$ to $92^{0} 21^{\prime} \mathrm{E}$ longitude. But there is no relation between the formative age of beachrock and latitude (Danjo and Kawasaki, 2012b).

Chemically, beachrock around the world differs in composition (Fig. 2). Beachrock at Tiruchendur, India, mainly consists of $\mathrm{Ca}$. In contrast, the beachrock in Vattakottai, India, is mainly Si- and Al-rich and that in Kanyakumari, India, is mainly $\mathrm{Fe}$ - and Ti-rich (Danjo and Kawasaki, 2012b) where Bangladesh is Si rich (Fig. 2). The main components of beachrocks and surrounding material are calcium carbonate or silica (Danjo and Kawasaki, 2013b). The proportion of $\mathrm{CaCO}_{3}$ in beachrocks was around $90 \%$ while the other portions consisted of $\mathrm{SiO}_{2}$, and $\mathrm{Al}_{2} \mathrm{O}_{3}$ in the Gulf of Mannar, India (Sahayam et al. 2010). The beachrocks in Bangladesh are mainly composed of calcium carbonate or silica, similar to the beachrocks in Japan and the world (Table 1).

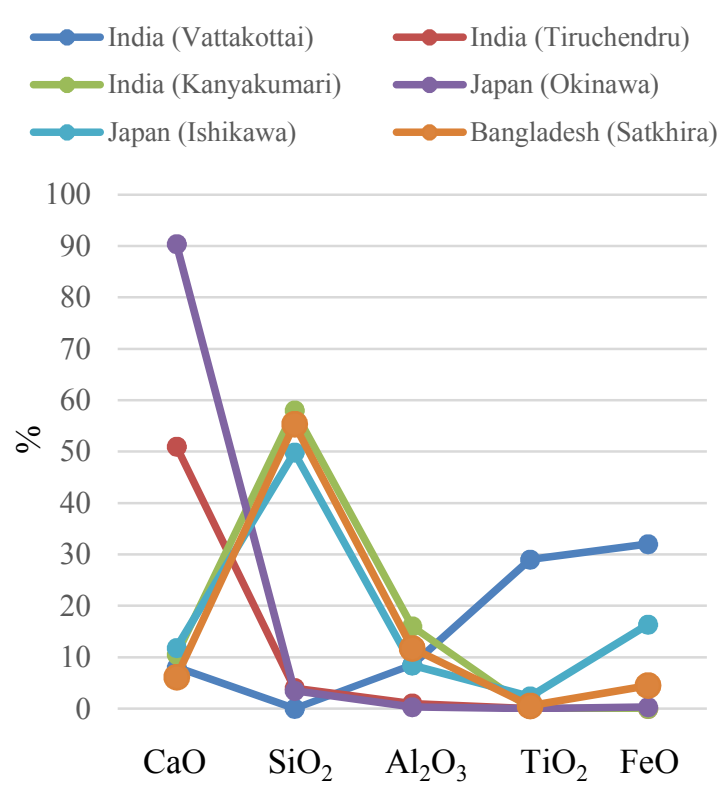

Fig. 2. Beachrock compositions around the world (Danjo and Kawasaki, 2012b)

Table 1. Compositions of some beachrocks in the world

\begin{tabular}{|c|c|c|c|c|}
\hline Location & $\begin{array}{l}\text { Component materials of the } \\
\text { beachrock }\end{array}$ & $\begin{array}{l}\text { Main minerals of } \\
\text { the beachrock }\end{array}$ & $\begin{array}{l}\text { Component materials } \\
\text { of the cement }\end{array}$ & Reference \\
\hline $\begin{array}{l}\text { Sumuide, Nago, } \\
\text { Okinawa, Japan }\end{array}$ & & Aragonite, Mgcalcite & Mg-calcite & Danjo et al. (2013b) \\
\hline $\begin{array}{l}\text { Sosogi, Wajima, } \\
\text { Ishikawa, Japan }\end{array}$ & $\begin{array}{l}\text { Sand, gravel, plastic piece, glass } \\
\text { piece, iron chain }\end{array}$ & & $\mathrm{Si}, \mathrm{Al}$ & $\begin{array}{l}\text { Ogasawara et al. } \\
(2004)\end{array}$ \\
\hline $\begin{array}{l}\text { Suzu, Ishikawa, } \\
\text { Japan }\end{array}$ & $\begin{array}{l}\text { Shell sand, foraminifer, sand, } \\
\text { gravel }\end{array}$ & $\begin{array}{l}\text { Quartz, feldspar, } \\
\mathrm{CaCO} 3\end{array}$ & $\mathrm{CaCO} 3$ & Azuma et al. (1982) \\
\hline Grand cayman & $\begin{array}{l}\text { Algae, mollusk, organic material, } \\
\text { coral grains }\end{array}$ & & & Moore (1973) \\
\hline Heron Island & Carbonate grains & & & Webb et al. (1999) \\
\hline Vattakottai, India & & $\begin{array}{l}\text { Calcite, aragonite, } \\
\text { quartz, heavy minerals }\end{array}$ & & $\begin{array}{l}\text { Ravisankar and } \\
\text { Rajalakshmi (2007) }\end{array}$ \\
\hline $\begin{array}{l}\text { Cox's Bazar, } \\
\text { Bangladesh }\end{array}$ & Sand, silt, clay & & & Brammer, 1996 \\
\hline $\begin{array}{l}\text { St. Martin, } \\
\text { Bangladesh }\end{array}$ & $\begin{array}{l}\text { calcareous coral sand, broken coral } \\
\text { or limestone }\end{array}$ & & & do. \\
\hline
\end{tabular}

\subsection{Beachrock formation}

Regarding the origin of beachrocks, two contrasting theories were proposed: one cited seawater as the source for beachrocks (Tanaka 1983, 1990) and the other claimed that groundwater or spring water was the source (Yonetani 1963, 1966). Opinions were divided between these two theories; and at the time, there was more support for the theory of seawater as the source for beachrock formation (Tanaka 1990). In this regards Danjo and Kawasaki (2013a) examined a formation mechanism of beachrock in Okinawa, Japan, understanding this natural formation mechanism of beachrock is an important step to making artificial beachrock. They focused on the cement formation mechanism of beachrock, which occurs in the intertidal zone. Cement type and content have the potential to influence the strength of the material; hence, detailed knowledge of beachrock cements would be valuable for producing an artificial equivalent (Danjo and Kawasaki, 2013a). Beachrocks are cemented by high $\mathrm{Mg}$ calcite (HMC) have been reported at 16 sites 
(Vousdoukas et al., 2007 and Erginal et al., 2010) around the world. Danjo and Kawasaki (2013a) focused investigation into the formation mechanisms of the beachrock cements on the influence of precipitation from seawater and/or seawater evaporation (PSW), and on surface microorganisms. Based on formation methods observed for Okinawa, Japan, artificial beachrock is cemented by HMC using microorganisms with urease activity, organic matter such as citrate and malate, nutrient sources, $\mathrm{CO}\left(\mathrm{NH}_{2}\right)_{2}$, artificial seawater and sand (Danjo and Kawasaki, 2014). With respect to PSW, Raz et al. (2000) reported that to better understand the depositional process of highmagnesian calcitic skeletons, they studied the $\mathrm{CaCO}_{3}$ precipitates formed from solutions with $\mathrm{Mg} / \mathrm{Ca}$ ratios $\geq 4$. In addition, according to experiments by Kitano and Kanamori (1966), sodium citrate and sodium malate favor the precipitation of MC, whereby an increase in concentration of magnesium ion and these organic materials cause formation of $\mathrm{Mg}$-rich calcite.

The sand properties of beach in Bangladesh are similar to the Japan, Silica sand and coral rich (Table 1), which would be very much suitable for artificial beachrock formation.

\section{CONCLUSIONS}

This bibliographical study has enabled us to gather information that should prove useful for the creation of artificial rocks that are modeled on beachrocks. In the future, it may possible to manufacture artificial rocks similar to beachrocks for erosion control purposes and it may also be possible in Bangladesh. Manufacturing of artificial rocks using compositional substances that are as similar as possible to those in beachrocks, and that follow the same formation process.

\section{REFERENCES}

1) Ali, A. (1999): Climate change impacts and adaptation assessment in Bangladesh, Climate Research, 12,109-116.

2) Association for Geological Collaboration in Japan (2000): Cyclopedia of earth science. Heibonsya, Tokyo, 1083-1084.

3) Azuma, Y., Fujii, S., Hatanaka, T. and Takeyama, K. (1982): Beachrock in Hokuriku, Japan, Quat Res, 20(4), 271-280.

4) Brammer, H. (1996): The geography of the soils of Bangladesh, University Press Limited, Dhaka - 1000, Bangladesh.

5) Bruun, P. (1962): Sea level rise as a cause of shore erosion, J. Waterways Harbors Div. Proc. Am. Soc. Civ. Eng., 88, 117-130.

6) Cruz, R.V., Harasawa, H., Lal, M., Wu, S., Anokhin, Y., Punsalmaa, B., Honda, Y., Jafari, M., Li, C. and Huu Ninh, N. (2007): Asia.
Climate Change 2007: Impacts, adaptation and vulnerability. contribution of working group II to the fourth assessment report of the intergovernmental panel on climate change, M.L. Parry, O.F. Canziani, J.P. Palutikof, P.J. van der Linden and C.E. Hanson, Eds., Cambridge University Press, Cambridge, UK, 469-506.

7) Danjo, T. and Kawasaki, S. (2014): Formation mechanisms of beachrocks in Okinawa and Ishikawa, Japan, with a Focus on Cements, Materials Transactions, 55(3), 493-500.

8) Danjo, T. and Kawasaki, S., (2013a): A study of the formation mechanism of beachrock in Okinawa, Japan: Toward Making Artificial Rock, Int. J. of GEOMATE, 5(1), pp. 633-638.

9) Danjo, T. and Kawasaki S. (2013b): Characteristics of beachrocks: a review, Geotech Geol Eng, Springer Science+Business Media Dordrecht, 215-246.

10) Danjo, T. and Kawasaki S. (2012a): Characteristics of beachrock based on bibliographical research: toward the development of man-made beachrock, J. of Japanese Society of Engineering Geology, 53(3), 129-151 (in Japanese with English abstract).

11) Danjo, T. and Kawasaki, S. (2012b): Property evaluation of beachrock based on field investigation in Okinawa Island, Japan, Harmonising Rock Engineering and the Environment - Qian \& Zhou (eds), Taylor and Francis Group, London, 949-952.

12) Danjo, T., Kawasaki, S. and Hata, T., (2012): Properties of beachrocks in Okinawa and Ishikawa, Japan, Proceedings of the 34th International Geological Congress, Brisbane, Australia.

13) Danjo, T., Kawasaki, S. and Hata, T. (2013a): Formation mechanisms of beachrocks in Okinawa and Ishikawa, Japan, Proceedings of the 47th US Rock Mechanics / Geomechanics Symposium, San Francisco, CA, USA.

14) Danjo, T., Kawasaki, S. and Hata, T., (2013b): Influencing factors of strength increase of beachrocks, Proceedings of the 13th Japan symposium on rock mechanics \& the 6th Japan Korea joint symposium, Okinawa, Japan, 617-622.

15) Erginal, A. E., Kiyak N. G. and Ozturk B. (2010): Investigation of beachrock using microanalyses and osl dating: a case study from Bozcaada Island, Turkey, J. of Coastal research, 26, 350-358.

16) Ginsburg, R. N. (1953): Beachrock in South Florida, J. Sediment. Petrol, 23, 85-92.

17) Hekstra, G. P. (1989), Global warming and rising sea levels: the policy implications, The Ecologist, 19, 4-15.

18) Islam, S. M. R., Huq S. and Ali, A. (1999): Beach erosion in the eastern coastline of Bangladesh, In: Huq, S., Karim, Z., Asaduzzaman, M. and 
Mahtab, F. (eds) Vulnerability and adaption to climate change for Bangladesh. Kluwer Academic Publishers, Dordrecht, 71-92.

19) Kitano, Y. and Kanamori, N. (1966): Synthesis of magnesian calcite at low temperatures and pressures, Geochemical Journal, 1, 1-13.

20) MCSP, (1992): Multipurpose cyclone shelter program. Final Report. Vol XI Special Studies, UNDP/World Bank/Govt of Bangladesh Project No. BGD/91/025.

21) Moore, C. H. (1973): Intertidal carbonate cementation in Grand Cayman, West Indies, $J$. Sediment Petrol, 43, 591-602.

22) Ogasawara, H., Yoshidomi, K. and Jiju K. (2004): Beachrock in Sosogi coast, Wajima, Noto peninsula, Japan, Proceedings of the JSEG Tyugoku-shikoku Meeting, Tottori, Japan, 31-34.

23) Pramanik, M. A. H. (1983): Remote sensing applications to coastal morphological investigations in Bangladesh, $P h D$ thesis, Jahangirnagar University, Savar, Dhaka.

24) Ravisankar, R. and Rajalakshmi, A. (2007): Gamma-ray spectroscopic and PIXE analysis of beach rock sample of south east coast of Tamilnadu, India, Int. J. PIXE 17(3\&4), 193-203.

25) Raz, S., Weiner, S. and Addadi L. (2000): Formation of high-magnesian calcites via an amorphous precursor phase: possible biological implications, Adv. Mater, 12, 38-42.

26) Sahayam, J. D., Chandrasekar, N., Kumar, S. K. and Rajamanickam, G. V. (2010): Distribution of arsenic and mercury in subtropical coastal beachrock, Gulf of Mannar, India, J. Earth Syst. Sci., 119(1), 129-135.

27) Tanaka, Y. (1983): A study on the foundation of beach rock in the Okinoerabu Islands, Geogr. Sci, 38(2), 91-101.

28) Tanaka, Y. (1990): Ishi ni natta sunahama: Bichirokku (Beachrocks in Japan). Tropics in Japan: natural history of coral islands. KokonShoin Ltd, Tokyo, 137-152.

29) Vousdoukas, M. I., Velegrakis, A. F. and Plomaritis, T. A. (2007): Beachrock occurrence, characteristics, formation mechanisms and impacts, Earth-Science Reviews, 85, 23-46.

30) Webb, G. E., Jell, J. S. and Baker, J. C. (1999): Cryptic intertidal microbialites in beachrock, Heron Island, Great Barrier Reef: implications for the origin of microcrystalline beachrock cement, Sediment Geol, 126, 317-334.

31) Yonetani, S. (1963): The preliminary studies on the beach rock of the northern part of Amami Oshima, south-west Japan, Geograph. Rev. Jpn., 36(9), 519-527.

32) Yonetani, S. (1966): The beach rock and its analogous land forms, Geograph. Rev. Jpn., 39(4), 240-250. 